\title{
Fast ion induced luminescence of silica implanted by molecular hydrogen
}

\author{
O.Kalantaryan, S.Kononenko, V.Zhurenko, N.Zheltopyatova \\ V. Karazin Kharkiv National University, 31 Kurchatov Ave., \\ 61108 Kharkiv, Ukraine
}

Received October 30, 2013

\begin{abstract}
We studied silica implanted by $420 \mathrm{keV} \mathrm{H}^{+}$and $210 \mathrm{keV} \mathrm{H}^{+}$ions up to absorption doses $3.5 \cdot 10^{21}$ particles per $\mathrm{cm}^{3}$ by ionoluminescence technique. We used some probe beams of molecular and atomic hydrogen ions for luminescence excitation from the implanted samples: $420 \mathrm{keV} \mathrm{H} \mathrm{H}^{+}, 210 \mathrm{keV}$ and $420 \mathrm{keV} \mathrm{H}$. It was found that significant changes in the spectrum shape of silica were observed at wavelength range of 550-650 nm during continuous ion irradiation. Using different probe beams we performed the comparative luminescence study of the silica samples implanted by $\mathrm{H}^{+}$and $\mathrm{H}^{+}$at the same absorption dose. For these samples we observed the difference in the spectra at wavelength range 610-650 nm, which corresponds to luminescence from non-bridge oxygen centers of silica. The possible explanation of the differences in the spectra shape was suggested.
\end{abstract}

Методом ионолюминесценции изучены люминесцентные свойства кварцевого стекла, имплантированного ионами $420 \mathrm{kэB} \mathrm{\textrm {H } ^ { + }}$ и $210 \mathrm{kэB} \mathrm{\textrm {H } ^ { + }}$ до поглощенных доз

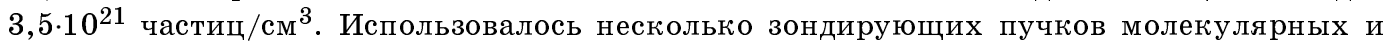
атомных ионов водорода для возбуждения люминесценции в имплантированных образцах: 420 кәВ $\mathrm{H}^{+}, 210$ кәВ и 420 кэВ $\mathrm{H}^{+}$. Обнаружено, что при длительном облучении ионами происходят значительные изменения в форме спектра кварца в диапазоне длин волн 550-650 нм. Используя различные зондирующие пучки, проведен сравнительный анализ люминесценции образцов кварца, имплантированных ионами $\mathrm{H}^{+}$и $\mathrm{H}^{+}$при одинаковых поглощенных дозах. Наблюдались различия в спектрах люминесценции в диапазоне длин волн 610-650 нм, который соответствует люминесценции кварца от дефектов типа немостикового кислорода. Предложено возможное объяснение различий в форме спектров.

Іонолюмінесценція квариу, що імплантований швидкими молекулярними іонали водню. О.Калантар'ян, С.Кононенко, В.Журенко, Н.Желтопятова.

Методом іонолюмінесценції вивчено люмінесцентні властивості кварцового скла, імплантованого іонами $420 \mathrm{\kappa eB} \mathrm{H^{+ }}$ та $210 \mathrm{keB} \mathrm{H^{+ }}$ до поглинених доз 3,5.10 21 частинок $/ \mathrm{cm}^{3}$. Використано декілька зондуючих пучків молекулярних і атомних іонів водню для збудження люмінесценції в імплантованих зразках: $420 \mathrm{\kappa eB} \mathrm{H} \mathrm{H}^{+}, 210$ кеВ та 420 кеВ $\mathrm{H}^{+}$. Виявлено, що при тривалому опромінюванні іонами відбуваються значні зміни у формі спектра кварцу у діапазоні довжин хвиль 550-650 нм. Використовуючи різні зондуючі пучки, проведено порівняльний аналіз люмінесценції зразків кварцу, імплантованих іонами $\mathrm{H}^{+}$та $\mathrm{H}^{+}$при однакових поглинених дозах. Спостерігалися відмінності у спектрах люмінесценції у діапазоні довжин хвиль 610-650 нм, який відповідає люмінесценції кварцу від дефектів типу немісткового кисню. Запропоновано можливе пояснення відмінностей у формі спектрів. 


\section{Introduction}

Using implantation to advance processing for a variety of device structures is becoming more important. Ion beams are used to modify optical properties of dielectric materials to fabricate optical waveguides, other related photonic devices, and novel crystal hosts.

Hydrogen ion implantation is widely used technique in many scientific and technical applications. Both atomic and molecular hydrogen ions are used for the implantation. For example, thin film exfoliation of a variety of different semiconductors - this technique is used to provide commercial silicon-on-insulator [1]. An additional advantage of using molecular ions is that the implantation depth can be reduced, what is of prime importance for advanced IC technologies. Molecular implantation offers semiconductor device manufacturers multiple advantages over traditional high current ion implanters. Moreover, investigation of dissociation of energetic molecular ions interacting with a solid is of considerable importance in a number of applications, e. g., cluster fusion and cluster ion deposition [2].

Silica is widely used material in many modern applications. For example, thin silica films grown on silicon wafers via thermal oxidation methods can be quite beneficial in microelectronics; hydrogen-passivation of dangling bonds at $\mathrm{Si} / \mathrm{SiO}_{2}$ interfaces is presently used as a standard processing step in the electronic devices fabrication (see, for example [3]). The implantation process results in creation of a hydrogensaturated layer in the quartz sample.

Ionoluminescence is a phenomenon of light emission from material being irradiated by ions and its spectra are in a considerable degree defined by intrinsic defects of a solid. Ion implantation results in defect formation in the solid. Then luminescence radiation (LR) study can be an effective tool to learn the defects generated by means of the ion irradiation and defect modification processes [4].

Luminescence is a very sensitive technique that is often applied for characterization of dielectric and semiconductor materials [5]. It provides information on the electronic structure of a solid, particularly defect centers inducing LR. Ionoluminescence is an appropriate technique to investigate the microscopic processes accompanying the creation of defects, its evolution with the irradiation fluence. Ionoluminescence is far less used that the other ion- beam analysis techniques because of the LR data are more complex.

In regard to silica, fast hydrogen ion bombardment is accompanied by LR in visible wavelength range due to the following defects: E'-centers or oxygen deficient centers (ODCs) and non-bridging oxygen hole centers (NBOHCs). These defects have a practical relevance because the transmittance of silica over a wide spectral range is reduced in this case.

Presence of implanted hydrogen both creates new defects and modifies the existing ones. As a result a luminescence spectrum changed. Earlier we showed that the luminescence spectrum changed under long-time ion irradiation. We established a connection between the luminescence spectrum shape and absorbed dose [6].

In this study, ionoluminescence was used to investigate features of formation and modification of the defects in silica exposed to the hydrogen ion implantation. The luminescence was induced by probe hydrogen ion beams (both atomic and molecular). The purpose of our work was to found differences in silica defect formation (ODCs and NBOHCs) after molecular or atomic implantation by means of the luminescence spectrum analysis.

\section{Experimental}

Experiments were performed on the setup described in details earlier [7]. Procedure of silica implantation was carried out with Van der Graaf accelerators. $210 \mathrm{keV}$ per nucleon hydrogen ion beam bombarded silica target at an incidence angle $\alpha=30^{\circ}$. The targets were prepared from $1 \mathrm{~mm}$ thick plane-parallel silica plate. Beam current density was varied up to $30 \mu \mathrm{A} / \mathrm{cm}^{2}$ (with fluency up to $2 \cdot 10^{14} \mathrm{~cm}^{-2}$ ). The average implantation dose was up to $3.5 \cdot 10^{21} \mathrm{~cm}^{-3}$ $\left(5 \cdot 10^{10} \mathrm{~Gy}\right)$.

LR was induced by hydrogen probe beams. The molecular or atomic probe beams with energies 210 and $420 \mathrm{keV}$ had current density from $0.3 \mu \mathrm{A} / \mathrm{cm}^{2}$ to $0.6 \mu \mathrm{A} / \mathrm{cm}^{2}$.

We used flexible light guide for independent change of observation angle $\beta$ in $0-70^{\circ}$ range. LR was collected from whole irradiated surface of the sample independently of $\beta$ angle. Luminescence spectra measurements were performed in the wavelength range of 400-700 $\mathrm{nm}$ by means of the grating monochromator $\left(1200 \mathrm{~mm}^{-1}\right.$, $1.3 \mathrm{~nm}$ per $\mathrm{mm}$ ). 
ION RANGES

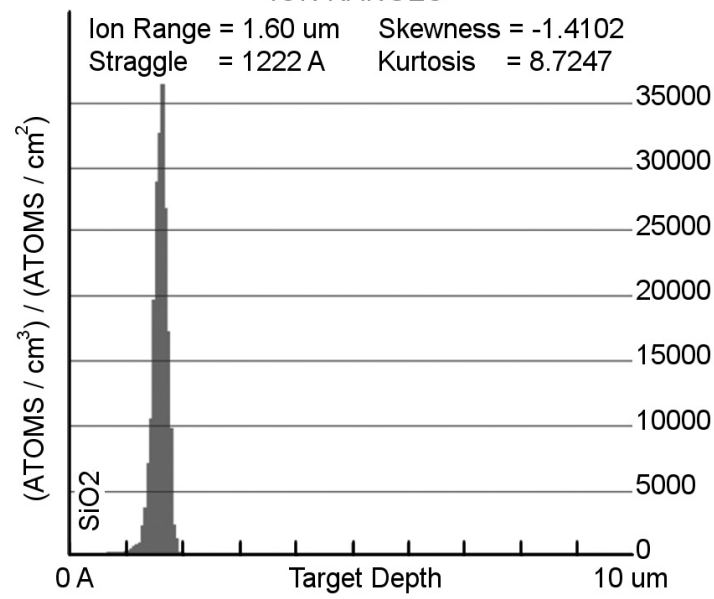

Fig. 1. Ion range distribution of $210 \mathrm{keV} \mathrm{\textrm {H } ^ { + }}$ implanted in silica (SRIM/TRIM).

Optical channels were calibrated with incandescence spectrometric lamp. The luminescence spectra were corrected according to the spectral sensitivity. Residual gas pressure was less than $10^{-4} \mathrm{~Pa}$. As luminescence light is generated along all of ion track in the solid, an influence of surface contamination on optical spectra can be neglected.

\section{Results and discussion}

Electronic energy losses of fast ion in a solid leads to LR generation by the defect excitation. It is well-known that ion induced luminescent spectra of silica consist of two wide bands in visible range of wavelength. ODCs (blue band) and NBOHCs (red band) are responsible for the light emission in these bands. These intrinsic silica defects are intensively produced in silica during the fast ion irradiation. The intrinsic silica defect profile for an unirradiated sample is determined by its production processes.

LR intensity is proportional to quantity of the defects generating light and value of the ionization losses. We performed SRIM TRIM calculation of $210 \mathrm{keV}$ proton passage through silica and found that $99.5 \%$ of its energy was ionization losses [8]. We measured LR from along ion track length because silica is transparent in visible wavelength range. Total luminescent light is defined by density of the ionization losses and correspondingly by the density of defects.

The TRIM simulation shown that impinged $210 \mathrm{keV}$ proton stopped in the thin

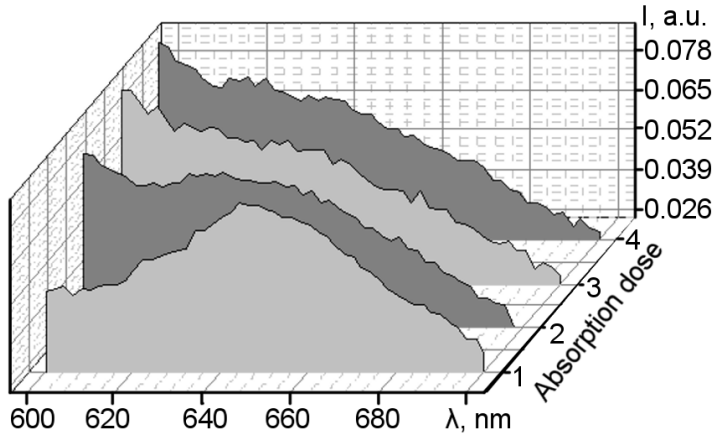

Fig. 2. Normalized luminescence spectra of silica implanted by $210 \mathrm{keV} \mathrm{H} \mathrm{H}^{+}$for different doses: $1-0.88 \cdot 10^{20} \mathrm{~cm}^{-3} ; 2-$ $16.3 \cdot 10^{20} \mathrm{~cm}^{-3} ; 3-24.9 \cdot 10^{20} \mathrm{~cm}^{-3} ; 4-$ $34.5 \cdot 10^{20} \mathrm{~cm}^{-3}$.

layer (Fig. 1). Thickness of this stopping layer was less than $8 \%$ of the path length. The implantation process was accompanied by hydrogen diffusion from the stopping layer. Impinging ions resulted in growth of diffusion coefficient. The radiation enhanced diffusion took place in this case. Diffusion hydrogen flux propagated in both directions from the stopping layer. Hydrogen flux to the sample surface was significantly more than the opposite direction [9].

It was well known that silica luminescent spectra depended on absorption dose of impinging ions [7]. We found evolution of the silica luminescent spectrum during $210 \mathrm{keV}$ proton implantation (see Fig. 2).

Presence of the implanted hydrogen atoms in silica could be resulted in modification of NBOHC and ODC. Fig. 2 shows that the luminescent spectra reveal contributions from the both intrinsic silica defects: blue band $\left(\lambda_{\max } \approx 456 \mathrm{~nm}\right)-\mathrm{ODC}$ and red band $\left(\lambda_{\text {max }} \approx 645 \mathrm{~nm}\right)-\mathrm{NBOHC}$. Moreover, the intensity of the blue band is much greater than for the red one. The LR spectra change during the implantation. Hydrogen diffusion processes influence on the luminescent spectrum shape. The intensity of the long wave wing of the blue band grows, while intensity of the red band decreases with absorption dose. This tendency takes place for all observation angles. Early we showed that the red band was virtually indistinguishable on long wave wing of the blue band after long proton irradiation [10]. The average density of implantation ions was up to $3 \cdot 10^{21} \mathrm{~cm}^{-3}$ (critical dose) $\left(4.4 \cdot 10^{10} \mathrm{~Gy}\right)$. The critical dose is defined as threshold after than the luminescent spectrum shape does not change. 


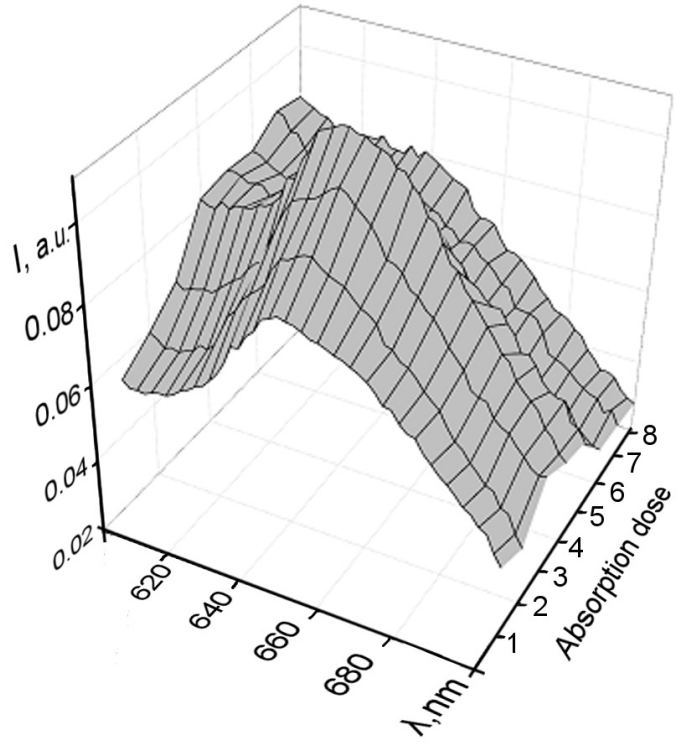

Fig. 3. Normalized luminescence spectra of silica implanted by $420 \mathrm{keV} \mathrm{H}_{2}{ }^{+}$for different doses: $1-0.6 \cdot 10^{20} \mathrm{~cm}^{-3} ; 2-6.1 \cdot 10^{20} \mathrm{~cm}^{-3}$; $3-11.1 \cdot 10^{20} \mathrm{~cm}^{-3} ; 4-14.9 \cdot 10^{20} \mathrm{~cm}^{-3}$, $5-17.7 \cdot 10^{20} \mathrm{~cm}^{-3} ; 6-24.1 \cdot 10^{20} \mathrm{~cm}^{-3}$; $7-27.1 \cdot 10^{20} \mathrm{~cm}^{-3} ; 8-30.3 \cdot 10^{20} \mathrm{~cm}^{-3}$.

For molecular ion implantation the dose dependence of spectrum shape was similar to mentioned above one until the critical dose (Fig. 3) [7]. The main difference for molecular case was observed in 600-700 nm wavelength range. The red band remained observable on the background for the dose more than critical one.

Fig. 4 shows the normalized luminescence spectra for different implantation species (absorption doses were more than the critical one) and probes: molecular (curve 1) and atomic hydrogen (curve 2). Normalization procedure of the luminescent spectra was described in details earlier (see, for example [11]). Measurement of the LR induced by probe beams was done after implantation process. The spectra differences are observed for area near $645 \mathrm{~nm}$. Molecular ion implantation does not lead to "disappearance" of the red band on the background as opposed to the proton implantation case. The spectrum of LR induced by probe proton beam from the molecular implanted sample (curve 3) is practically the same with one induced by probe molecular beam (curve 1). This effect takes place for the all observation angles.

The major part of the energy losses of projectiles transferred to the electron subsystem. As a result, ODCs and NBOHCs

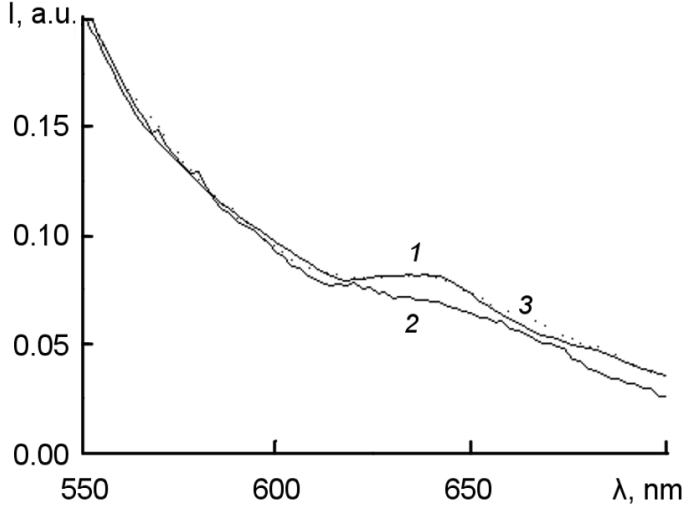

Fig. 4. Normalized spectra of silica implanted up to $3 \cdot 10^{21} \mathrm{~cm}^{-3}$ dose: 1 - implanted by $420 \mathrm{keV} \mathrm{H}_{2}^{+}$, probe beam $-420 \mathrm{keV} \mathrm{H}_{2}^{+}$; 2 - implanted by $210 \mathrm{keV} \mathrm{H}^{+}$, probe beam $210 \mathrm{keV} \mathrm{H}^{+}$; 3 - implanted by $420 \mathrm{keV} \mathrm{H}_{2}{ }^{+}$, probe beam $-210 \mathrm{keV} \mathrm{H}^{+}$.

were produced in silica. Implanted hydrogen modified these defects. Thus, there are two processes: defect creation and defect modification by the implanted hydrogen. Namely, balance between these processes defined the luminescent spectrum shape. As it can be seen from Fig. 4 (curve 1) the balance shifted towards NBOHC defect creation in the molecular ion implantation case in comparison with the atomic one (curve 2).

Passage of molecular ion through a matter has some features. When $\mathrm{MeV}$ or sub$\mathrm{MeV} \mathrm{H}_{2}{ }^{+}$molecular ion impinges on a target the binding electron of $\mathrm{H}_{2}{ }^{+}$is stripped off rapidly by a collision with the target atom and the remaining two protons dissociate via mutual Coulomb force in the solid. This is referred to as the "Coulomb explosion" [2].

Since the work by Brandt, Ratkowski, and Ritchie [12], it has been known that the energy loss of the pair is not given by twice that of the individual proton. This nonlinearity arises from the so-called vicinage effect, where the stopping power for a pair of protons differs from twice the stopping power for individual protons due to the superposition of wake potentials induced by the both fragments. Authors of [12] experimentally studied energy loss of 75 and $150 \mathrm{keV}$ per nucleon atomic and molecular hydrogen ion beams passing through foils of carbon and gold. The molecular energy losses per nucleon exceeded the atomic one by as much as $20 \%$. Similar results obtained for the hydrogen ion passage with energies of 0.3 to $1 \mathrm{MeV} /$ nucleon from thin carbon foils (200-2000 ̊) [13]. 
The molecular ion produces more high energy electrons in comparison with two atomic ones at the same velocity [14]. Moreover, high energy secondary electrons $(\delta$ electrons, convoy electrons etc.) produce own short tracks [15]. Thus the both fast ions and high energy secondary electrons transfer energy into NBOHC production and luminescence light excitation. Cathodoluminescent experiments shown that electrons more effectively excited NBOHC's luminescent band than ODC's ones [16].

As opposed to the red band luminescence from the NBOHC, the blue band luminescence intensity from the ODCs increased with absorption dose. It is implied relative contributions from the blue and red bands to the normalized spectrum. The possible reason is the fact that implanted hydrogen modified the NBOHC and keeps the ODC's in active emission states [16].

We also used $420 \mathrm{keV} \mathrm{H}^{+}$probe beam. The spectrum shape is differed from the ones for nonirradiated and implanted up to the critical dose samples. Because of path length of ion depends on energy, this projectile passed through irradiated and nonirradiated areas of the sample. In this case we obtained silica integral luminescence spectra both from the hydrogen irradiated area and nonirradiated area. Substantial differences of this spectrum from the mentioned above ones $\left(420 \mathrm{keV} \mathrm{H}_{2}{ }^{+}\right.$probe beam) enabled to conclude that significant radiation enhanced diffusion toward to surface of the sample.

\section{Conclusion}

We performed comparative experimental study of the ionoluminescence induced from silica implanted either molecular or atomic hydrogen ions. We observed difference in the luminescence spectrum shapes for these samples. It was found that radiation enhanced diffusion leads to the spectrum shape change during the implantation. The molecular hydrogen ion implantation in comparison with the atomic case leads to shift of the dynamic equilibrium between creation and modification of NBOHC toward the former. We obtained a satisfactory evidence of the difference in implantation process for the molecular and atomic hydrogen ions for the doses more than $4.4 \cdot 10^{10} \mathrm{~Gy}$. Possible explanation was suggested for interpretation of the results obtained. The contribution of the fast electrons created by ions in silica can be considered as a possible reason for the difference in the implantation process.

\section{References}

1. Mark Goorsky, Ion implantation. InTech, Rijeka (2012).

2. Y.Susuki, Phys. Rev.A, 56, 2918 (1997).

3. A.Luna-Lopez, M.Aceves-Mijares, O.Malik, Sensors Actuators, A132, 278 (2006).

4. O.Kalantaryan, S.Kononenko, V.Zhurenko, Functional Materials, 20, 262 (2013).

5. D.Jimenez-Rey, O.Pena-Rodriguez, J.Manzano-Santamaria et al., Nucl. Instr. Meth. Phys. Res., B286, 282 (2012).

6. S.Kononenko, O.V.Kalantaryan, V.I.Muratov et al., Rad. Meas., 42, 751 (2007).

7. O.Vasylchenko, N.Zheltopyatova, V.Zhurenko et al., Functional Materials, 17, 67 (2010).

8. J.F.Ziegler, J.P.Biersack, U.Littmark, Nucl. Instr. Meth. Phys. Res., B268, 1818 (2010).

9. Yu.Borisenko, V.Gritsyna, S.Litovchenko et al., Zh. Tekh.Fiz., 69, 112 (1999).

10. S.Kononenko, O.Kalantaryan, V.Muratov, Ch.Namba, J.Plasma Fusion Res. SERIES, 7, 135 (2006).

11. S.Kononenko, O.Kalantaryan, V.Muratov et al., Nucl. Instr. Meth. Phys. Res., B246/2, 340 (2006).

12. W.Brandt, A.Ratkowski, R.H.Ritchie, Phys. Rev. Lett., 33, 1325 (1974).

13. J.W.Tape, W.M.Gibson, J.Remillieux et al., Nucl. Instr. Meth. Phys. Res., 132, 75 (1976).

14. D.Hasselkamp, Springer Tracts Modern Phys., 123, 1 (1992).

15. N.Z.Galunov, V.P.Seminozhenko, Teoriya i Primenenie Radiolyuminestsentsii Organicheskikh Kondensirovannykh Sred, Naukova dumka, Kiev (1997) [in Russian].

16. H.-J.Fitting, T.Ziems, Roushdey Salh et al., J. Non-Crystal. Solids, 351, 2251 (2005). 